\title{
Chemical synthesis, characterisation and in vitro and in vivo metabolism of the synthetic opioid MT-45 and its newly identified fluorinated analogue 2F-MT-45 with metabolite confirmation in urine samples from known drug users
}

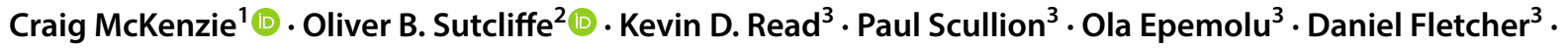

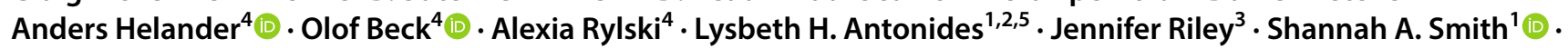 \\ Niamh Nic Daeid ${ }^{1,5}$
}

Received: 19 December 2017 / Accepted: 21 March 2018 / Published online: 5 April 2018

(c) The Author(s) 2018

\begin{abstract}
Purpose The detection of a novel psychoactive substance, 2F-MT-45, a fluorinated analogue of the synthetic opioid MT-45, was reported in a single seized tablet. MT-45, 2F-, 3F- and 4F-MT-45 were synthesised and reference analytical data were reported. The in vitro and in vivo metabolisms of MT-45 and 2F-MT-45 were investigated.

Method The reference standards and seized sample were characterised using nuclear magnetic resonance spectroscopy, ultraperformance liquid chromatography-quadrupole time of flight mass spectrometry, gas chromatography-mass spectrometry, attenuated total reflectance-Fourier transform infrared spectroscopy and Raman spectroscopy. Presumptive tests were performed and physicochemical properties of the compounds determined. Metabolite identification studies using human liver microsomes, human hepatocytes, mouse hepatocytes and in vivo testing using mice were performed and identified MT-45 metabolites were confirmed in authentic human urine samples.

Results Metabolic pathways identified for MT-45 and 2F-MT-45 were $N$-dealkylation, hydroxylation and subsequent glucuronidation. The major MT-45 metabolites identified in human in vitro studies and in authenticated human urine were phase I metabolites and should be incorporated as analytical targets to existing toxicological screening methods. Phase II glucuronidated metabolites were present in much lower proportions.

Conclusions 2F-MT-45 has been detected in a seized tablet for the first time. The metabolite identification data provide useful urinary metabolite targets for forensic and clinical testing for MT-45 and allows screening of urine for 2F-MT-45 and its major metabolites to determine its prevalence in case work.
\end{abstract}

Keywords Novel psychoactive substances $\cdot$ MT-45 - 2F-MT-45 $\cdot$ Metabolite identification $\cdot$ Synthetic opioids $\cdot$ Clinical and forensic toxicology

Electronic supplementary material The online version of this article (https://doi.org/10.1007/s11419-018-0413-1) contains supplementary material, which is available to authorized users.

Craig McKenzie

c.t.mckenzie@dundee.ac.uk

$\triangle$ Oliver B. Sutcliffe

o.sutcliffe@mmu.ac.uk

1 Forensic Drug Research Centre, Centre for Anatomy and Human Identification, School of Science and Engineering, University of Dundee, Dundee, UK

2 Division of Chemistry and Environmental Science, School of Science and the Environment, Manchester Metropolitan University, Manchester, UK
3 Drug Discovery Unit, School of Life Sciences, University of Dundee, Dundee, UK

4 Department of Laboratory Medicine, Karolinska Institutet and Karolinska University Laboratory, Stockholm, Sweden

5 Leverhulme Research Centre for Forensic Science, School of Science and Engineering, University of Dundee, Dundee, UK 


\section{Introduction}

MT-45 [1-cyclohexyl-4-(1,2-diphenylethyl)piperazine], also known as IC-6, NSC 299236 and CDEP, is a synthetic opioid developed as a therapeutic drug candidate in the 1970s by the Dainippon Pharmaceutical Co. in Japan. MT-45 has never been commercially available as a therapeutic agent; however, it has appeared on the illicit recreational drug market in recent years, but not extensively [1-6]. MT-45 is structurally distinct from other therapeutic opioids (Fig. 1a) and has structural similarities to the dissociative drug diphenidine (Fig. 1f) which is an $N$-methyl-D-aspartic acid (NMDA) receptor agonist. MT-45 is a selective $\mu$-opioid receptor (MOR-1) agonist showing $\mathrm{nM}$ binding affinities to MOR-1, but is less potent than morphine, with considerably lower $\delta$ - and $\kappa$-opioid receptor (DOR-1 and KOR-1) affinities [1]. The racemic mixture has opioid-like properties in animal models with a potency similar to morphine, with the $(S)$-enantiomer being considerably more potent than the $(R)$-isomer [4, 7-11]. Antinociceptive (reduced sensitivity to pain) effects were studied in vivo using a radiant heat tail flick assay in mice, showing that MT-45 had analgesic properties similar to morphine [1], which were further confirmed by Montesano et al. [12]. Users reporting their subjective experiences with the drug on online fora have often reported dissociative effects after consuming MT-45 [13-15], and such effects may be mediated via the NMDA receptor; however, no formal studies on the NMDA receptor affinity of MT-45 or its metabolites have been reported.

MT-45 was first detected on the illicit market in seized samples in Japan [16] and was first reported in Europe by the STRIDA project in Sweden in nine nonfatal intoxication cases [17]. Detection of MT-45 in biological fluids was reported to the European Monitoring Centre for Drugs and Drug Addiction (EMCDDA) in relation to 28 fatal and 12 nonfatal intoxications in Sweden, the substance being implicated in 19 of the fatalities either as the cause of death or as a contributing factor and was commonly detected with other psychoactive substances [18]. Unusual side effects, including hearing impairment and loss, severe bilateral cataracts, folliculitis and dermatitis were reported in individuals following nonfatal intoxications with MT-45 [17, 19, 20]. In the USA, MT-45 and the benzodiazepine etizolam were detected and quantified in whole femoral blood relating to a drug-related fatality (520 and $35 \mathrm{ng} / \mathrm{mL}$, respectively), and MT-45 was also detected in urine, vitreous humor and bile [21]. Two further MT-45-related fatalities were reported in the USA in 2013 [22]. MT-45 was detected $(2900 \mathrm{ng} / \mathrm{mL})$ in postmortem femoral blood in a German fatality, where the user appeared to die shortly after taking the drug [23]. Both<smiles>[C+]1CCC(N2CCN(C(Cc3ccccc3)c3ccccc3)CC2)CC1</smiles><smiles>Fc1ccccc1C(Cc1ccccc1)N1CCN(C2CCCCC2)CC1</smiles><smiles>Fc1cccc(C(Cc2ccccc2)N2CCN(C3CCCCC3)CC2)c1</smiles><smiles>Fc1ccc(C(Cc2ccccc2)N2CCN(C3CCCCC3)CC2)cc1</smiles>

e<smiles>Fc1ccccc1C(Cc1ccccc1)N1CCCC1</smiles>

$\mathbf{f}$<smiles>c1ccc(CC(c2ccccc2)N2CCCCC2)cc1</smiles>

g<smiles>COc1ccccc1C(Cc1ccccc1)N1CCCCC1</smiles>

Fig. 1 Chemical structures of a MT-45, including the structural notation used for nuclear magnetic resonance (NMR) spectroscopy data using the system reported by [16], b 2F-MT-45, c 3F-MT-45, d 4F-MT-45, e 2FPPP (fluorolintane), f diphenidine and g 2-methoxphenidine (2-MXP) 
Papsun et al. [21] and Fels et al. [23] noted that MT-45 in femoral blood appeared unstable (and of unknown stability in other matrices) with concentrations decreasing $>50 \%$ from original concentrations over approximately 1 year, despite samples being stored at $-20^{\circ} \mathrm{C}$ until analysis; however, the breakdown products of MT- 45 have not been identified. Reviews of the scientific literature related to MT-45 [2, 24-26] highlight a lack of availability of metabolic studies, although one such study has recently been published providing in vitro data using rat hepatocytes and in vivo data in mice [12].

A review of the prevalence of MT-45, its mode of use and user experiences taken from online fora is available, together with a report on MT-45 anecdotally being seen as a relatively undesirable recreational drug [27, 28]. In the UK, MT-45 was designated a Class A substance under the Misuse of Drugs Act 1971 (as amended) in February 2015 and is a Schedule 1 substance in the Misuse of Drugs Regulations 2001 (as amended) having no legitimate medical application [24]. In May 2016, MT-45 was brought under international control by the United Nations Office for Drugs and Crime (UNODC) as a Schedule I substance under the Single Convention on Narcotic Drugs of 1961, as amended by the 1972 Protocol [25]. In July 2017, it was listed as a controlled substance by China, prohibiting its sale and export, one of 138 substances controlled in this way since 2015 [29]. One common response of novel psychoactive substance (NPS) drug synthesis laboratories supplying the illicit drug market, most commonly, but not exclusively, located in China, following a legislative ban, is to manipulate the structure of the banned substance to a small degree, evading the ban but retaining similar effects and potency. One such manipulation is the substitution of a hydrogen atom on the molecule with a fluorine atom. It might be expected therefore that, following the ban, fluorinated analogues of MT-45 may appear on the illicit drug market.

This study reports the first known identification of a fluorinated MT-45 analogue, detected in a tablet recovered in Manchester, UK, in October 2016, and describes the substance's analytical characterization and the synthesis of three fluorinated MT-45 analogue reference standards (2F-, 3Fand 4F-MT-45) to unequivocally confirm identity. This study also reports the elucidation and identification of phase I and II metabolites of MT-45 and, for the first time, 2F-MT-45. The in vitro and in vivo metabolisms of MT- 45 and 2F-MT45 have been studied using human liver microsomes, human hepatocytes, mouse hepatocytes and mouse in vivo testing, and the data from the different techniques are compared as well to previously published MT-45 metabolite identification data [12]. MT-45 metabolites identified in vitro and mouse in vivo studies have, for the first time, been analytically confirmed in reanalysed human urine samples from individuals known to have ingested MT-45.

\section{Materials and methods}

\section{Synthesis of reference standards}

1-Cyclohexyl-4-(1,2-diphenylethyl)piperazine dihydrochloride (MT-45, Fig. 1a) and its fluorinated derivatives (2FMT-45, Fig. 1b; 3F-MT-45, Fig. 1c; 4F-MT-45, Fig. 1d) were prepared using an adaptation of the method reported by Geyer et al. [30]. The products were structurally characterized by ${ }^{1} \mathrm{H}$ nuclear magnetic resonance (NMR), ${ }^{13} \mathrm{C}$ NMR, ${ }^{19} \mathrm{~F}$ NMR, gas chromatography-mass spectrometry (GC-MS), attenuated total reflectance-Fourier transform infrared (ATR-FTIR) spectroscopy and Raman spectroscopy (see supplementary material). Yields of products (after recrystallization from diethyl ether): 1-cyclohexyl-4-(1,2diphenylethyl)piperazine dihydrochloride (MT-45, 20\%); 1-cyclohexyl-4-(1-(2-fluorophenyl)-2-phenylethyl)piperazine dihydrochloride (2F-MT-45, 18\%); 1-cyclohexyl-4-(1(3-fluorophenyl)-2-phenylethyl)piperazine dihydrochloride (3F-MT-45, 19\%); 1-cyclohexyl-4-(1-(4-fluorophenyl)2-phenylethyl)piperazine dihydrochloride (4F-MT-45, 18\%).

\section{Seized illicit tablet}

An off-white/cream square tablet in a clear snap-bag labelled with "2FPPP", an alternative name for the dissociative drug fluorolintane, was submitted to Manchester Metropolitan University via Greater Manchester Police on the 15th October 2016 following the Mantra Festival, Greater Manchester, UK. The tablet was $6 \mathrm{~mm}$ in length $\times 6 \mathrm{~mm}$ width $\times 4 \mathrm{~mm}$ in



Fig. 2 Photograph of off-white/cream square tablet (in a clear snapbag labelled with "2FPPP"), with 6-mm length, 6-mm width and 4-mm height/depth 
height/depth. The molecular structure of 2FPPP is shown in Fig. 1e and the seized tablet is shown in Fig. 2.

\section{Chemical characterisation}

GC-MS analysis was carried out on 1-mg/mL sample analyte solutions in high-performance liquid chromatography (HPLC) grade methanol using a 7820A gas chromatograph coupled to a 5977E mass spectrometer (Agilent Technologies, Santa Clara, CA, USA). Injection mode: $1-\mu \mathrm{L}$ sample injection and 25:1 split, injection port temperature: $250{ }^{\circ} \mathrm{C}$, carrier gas: He, flow: $1 \mathrm{~mL} / \mathrm{min}$. Column: DB1MS, $25 \mathrm{~m} \times 0.2 \mathrm{~mm}$ i.d., film thickness $0.33 \mu \mathrm{m}$ (Agilent Technologies). GC oven: $40{ }^{\circ} \mathrm{C}$ held for $1 \mathrm{~min} ; 40^{\circ} \mathrm{C} / \mathrm{min}$ to $300{ }^{\circ} \mathrm{C}$ held for $4 \mathrm{~min}$. Transfer line: $280^{\circ} \mathrm{C}$. The mass spectrometer was operated in electron ionization (EI) mode. Ionization conditions: $70 \mathrm{eV}$ in full scan mode (50-550 amu), ion source: $230{ }^{\circ} \mathrm{C}$, quadrupole: $150{ }^{\circ} \mathrm{C}$.

ATR-FTIR spectroscopy was carried out using a CARY 630 system (Agilent Technologies).

NMR spectroscopy analyses were performed using a Bruker AVANCE III HD 500-MHz spectrometer (Bruker, Billerica, MA, USA) running under TopSpin v.3.2.5 equipped with a QCI-F cryo-probe at a sample compartment temperature of $25^{\circ} \mathrm{C}$. Samples were prepared in $\mathrm{CDCl}_{3}$ $(\sim 10 \mathrm{mg}$ in $1 \mathrm{~mL})$. Two drops of saturated sodium bicarbonate in $\mathrm{D}_{2} \mathrm{O}$ was added and the samples shaken thoroughly to extract the salt. Once the layers of $\mathrm{CDCl}_{3}$ and $\mathrm{D}_{2} \mathrm{O}$ had fully separated, a $0.7-\mathrm{mL}$ aliquot of the $\mathrm{CDCl}_{3}$ layer was recovered and transferred to NMR tubes for analysis. The data was analysed using TopSpin v.3.2.3. The residual solvent signals at $\delta=7.26 \mathrm{ppm}$ for ${ }^{1} \mathrm{H}$ and $\delta=77.16 \mathrm{ppm}$ for ${ }^{13} \mathrm{C}$ were used as internal references. Hexafluorobenzene was used to reference the ${ }^{19} \mathrm{~F}$ spectra $(\delta=-164.9 \mathrm{ppm})$. Characterisation of the compound was performed using ${ }^{1} \mathrm{H}$ NMR, ${ }^{13} \mathrm{C}$ NMR $\left({ }^{1} \mathrm{H}\right.$ decoupled $),{ }^{19} \mathrm{~F}$ NMR $\left({ }^{1} \mathrm{H}\right.$ decoupled $)$, double-quantum filtered correlated spectroscopy (COSY-DQF), 1-bond ${ }^{1} \mathrm{H}$ ${ }^{13} \mathrm{C}$ distortionless enhancement by polarisation transfer (DEPT)-135 edited heteronuclear single quantum correlation (HSQC) spectroscopy, ${ }^{1} \mathrm{H}-{ }^{13} \mathrm{C}$ heteronuclear multiple bond coherence (HMBC) spectroscopy, nuclear Overhauser enhancement spectroscopy (NOESY) and ${ }^{19} \mathrm{~F}-{ }^{1} \mathrm{H}$ heteronuclear Overhauser enhancement spectroscopy (HOESY; see supplementary material for all spectral characterisations). The numbering scheme for the structure is shown in Fig. 1a [16].

Ultra-performance liquid chromatography-quadrupole time-of-flight mass spectrometry (UPLC-QToF-MS) of the synthesised reference standards and metabolomics samples was performed using an Acquity UPLC instrument consisting of a binary pump, autosampler (held at $4{ }^{\circ} \mathrm{C}$ ), vacuum degasser and column oven (held at $40^{\circ} \mathrm{C}$ ) coupled to a XevoQToF (Waters Corporation, Milford, MA, USA). Mobile phases were (A) LC-MS grade water with $0.1 \%$ formic acid and (B) acetonitrile with $0.1 \%$ formic acid. The gradient used was: $0.0-0.5 \mathrm{~min}$ : $2 \% \mathrm{~B}$; 0.5-5.0 $\mathrm{min}$ : $2-95 \%$ B; $5.0-5.99 \mathrm{~min}: 95 \% \mathrm{~B}$; and $6.0-7.0 \mathrm{~min}: 2 \% \mathrm{~B}$ for equilibration. Flow rate was $0.5 \mathrm{~mL} / \mathrm{min}$ and $2 \mu \mathrm{L}$ of sample was injected onto a BEH $\mathrm{C}_{18} 50 \times 2.1 \mathrm{~mm}, 1.7 \mu \mathrm{m}$ particle size column (Waters Corporation). The QToF was operated in positive ionisation mode with a source temperature at $120{ }^{\circ} \mathrm{C}$, a desolvation temperature at $500{ }^{\circ} \mathrm{C}$ and a capillary voltage at $2.25 \mathrm{kV}$. QToF-MS analysis was carried out with a collision energy at $6 \mathrm{~V}$ and $\mathrm{QToF} \mathrm{MS}^{\mathrm{e}}$ acquisition was carried out using collision energy ranging from 20 to $40 \mathrm{~V}$. Once QToF-MS, and MS ${ }^{\mathrm{e}}$ data were processed, MS/MS data acquisition was utilised for selected parent ion accurate mass data to determine accurate product ion data.

Raman spectroscopy was performed using a proprietary analytical system developed at the University of Dundee (see supplementary material).

The $\mathrm{p} K \mathrm{a}$-basic and partition coefficient $(\log P)$ values for MT-45 and its fluorinated analogues were experimentally derived using a Sirius T3 system (Sirius Analytical Instruments, Sussex, UK).

A range of presumptive colour tests were carried out using 1-2 mg of the synthesised reference standards and the seized tablet, with reagents prepared and tests performed in accordance with UNODC guidelines [31].

\section{Metabolite identification}

Full method details for the in vitro metabolite identification studies are provided in the supplementary material.

\section{Pooled human liver microsome incubations}

MT-45, 2F-MT-45 and positive controls were incubated in pooled human liver microsome (pHLM; Thermo Fisher Scientific, Waltham, MA, USA) incubations at $37^{\circ} \mathrm{C}$ with and without uridine $5^{\prime}$-diphosphoglucuronic acid (UDPGA). Verapamil was used as the positive control for incubations without UDPGA (phase I metabolism) and propranolol as the positive control for incubations with UDPGA (phase II metabolism). Procedure: $450 \mu \mathrm{L}$ of liver microsomes $(1.11 \mathrm{mg} / \mathrm{mL})$ and $45 \mu \mathrm{L}$ of cofactor (nicotinamide adenine dinucleotide phosphate (NADPH) or UDPGA/NADPH) were added to wells of a 96-deep-well 2-mL plate (incubation plate) kept at $37{ }^{\circ} \mathrm{C} ; 5 \mu \mathrm{L}$ of $5 \mu \mathrm{M}$ test compound in dimethyl sulphoxide (DMSO; Fisher Scientific, Loughborough, UK) was added and a 50- $\mu \mathrm{L}$ aliquot of the incubation mixture was immediately removed and added to $200 \mu \mathrm{L}$ of acetonitrile (ACN; Fisher Scientific) to terminate the reaction, providing an initial $(t=0)$ sample. Further, $50-\mu \mathrm{L}$ aliquots of the incubation mixtures were removed at 5, 15, 30 and $60 \mathrm{~min}$. All samples were centrifuged to sediment any 
precipitated protein (3270 rpm for $10 \mathrm{~min}$ ). A $150-\mu \mathrm{L}$ volume of the supernatant was removed, diluted with $50 \mu \mathrm{L}$ of Milli-Q water in a 96 deep-well 2-mL plate (analysis plate) and sealed prior to analysis by UPLC-QToF-MS.

\section{In vitro human and mouse hepatocyte incubations}

Metabolic stability studies were performed using cryopreserved hepatocytes; either mouse (Mheps: mouse CD1 Cryo Hep Female Suspension Pool 20 Donor, 4-8 million recoverable cells, MSCS20; Thermo Fisher Scientific) or human (Hheps: Human Cryo Hep Suspension Pool 50 Donor, mixed gender, HMCS50; Thermo Fisher Scientific). 7-Ethoxycoumarin and 7-hydroxycoumarin were used as positive controls. Reaction initiation and sampling: $200 \mu \mathrm{L}$ of working solution containing test compound at $5 \mu \mathrm{M}$ in DMSO was added to $200 \mu \mathrm{L}$ of cell suspension to initiate the reaction. A $20-\mu \mathrm{L}$ aliquot of the incubation mixture was removed immediately and added to $80 \mu \mathrm{L}$ of acetonitrile containing an internal standard ( $50 \mathrm{ng} / \mathrm{mL}$ donepezil). Further $20-\mu \mathrm{L}$ aliquots were removed to a 96 deep-well 2-mL plate (analysis plate) at the following timepoints: 3, 6, 9, 15, 30, 60, 90 and $120 \mathrm{~min}$. A $100-\mu \mathrm{L}$ volume of water/acetonitrile (80:20, $\mathrm{v} / \mathrm{v}$ ) was added to all samples and the analysis plate was centrifuged at $2800 \mathrm{rpm}$ for $10 \mathrm{~min}$ at room temperature prior to injection and analysis of samples by UPLC-QToF-MS.

\section{In vivo mouse metabolite identification studies}

MT-45 and 2F-MT-45 were dosed orally by gavage as a solution at $10 \mathrm{mg}$ free base $/ \mathrm{kg}$ (dose volume: $10 \mathrm{~mL} / \mathrm{kg}$; dose vehicle: $1.0 \%$ carboxymethyl cellulose) to female $\mathrm{C} 57 \mathrm{BJ} / 6 \mathrm{~J}$ mice $(n=1 /$ compound). Blood samples $(10 \mu \mathrm{L})$ were taken from each mouse tail vein pre-dose and then at $0.5,1,2,4,8$ and $24 \mathrm{~h}$, mixed with 9 volumes of distilled water and stored frozen until analysed. The 24-h urine samples were also collected for metabolite identification studies. The blood and urine samples were subjected to UPLC-QToF-MS analysis and the metabolites were identified. All samples were processed using MetaboLynx-XS software (Waters Corporation) to identify possible metabolites from MS data. The list was reduced by a manual check of the data and an MS/ MS analysis was performed on peaks accepted as genuine metabolites.

\section{Human metabolite identification studies}

In addition to the identification of MT-45 metabolites identified in the in vitro and mouse in vivo, the study in human urinary analysis was carried out using urine samples collected from two analytically confirmed intoxication cases, two males aged 17 and 26 years (full details are provided in [17]) enrolled in the Swedish STRIDA project on NPS [17,
19]. The 17-year-old had $102 \mathrm{ng} / \mathrm{mL}$ of MT-45 in blood and $43 \mathrm{ng} / \mathrm{mmol}$ of creatinine in urine. 11-Nor-9-carboxy- $\Delta^{9}$ tetrahydocannabinol, dextromethorphan and methiopropamine were also detected in his urine. The 26-year-old had $39 \mathrm{ng} / \mathrm{mL}$ of MT-45 in blood and $200 \mathrm{ng} / \mathrm{mmol}$ of creatinine in urine and 3-methoxyphencyclidine was also detected. The urine samples had been stored at $-80{ }^{\circ} \mathrm{C}$ since the time of sampling to reanalysis for this study. The analysis was done by HPLC combined with high-resolution mass spectrometry (HRMS), essentially as detailed elsewhere [32, 33], and involved a targeted search for the metabolites already identified in the human and mouse in vitro and mouse in vivo studies.

\section{Results}

\section{Chemical characterisation of synthesised reference standards}

UPLC-QToF-MS, GC-MS, ATR-FTIR spectroscopy, NMR $\left({ }^{1} \mathrm{H},{ }^{13} \mathrm{C}\right.$ and $\left.{ }^{19} \mathrm{~F}\right)$ spectroscopy and Raman spectroscopy data and experimentally derived $\mathrm{p} K \mathrm{a}$ 's, $\log P$ (octanol/water) and $\log D_{7.4}$ (octanol/water) values for the characterisation of the synthesised reference standards were provided (see supplementary material, section C). $\log P$ is the partition coefficient of the non-ionised form of the analyte, whilst $\log D$ is the $\mathrm{pH}$-dependent coefficient of distribution for ionisable compounds such as the MT-45s at the physiological $\mathrm{pH}(\mathrm{pH}$ 7.4).

The MT-45 and fluorinated analogue reference standards were tested using a range of commonly used presumptive tests (see supplementary material). MT-45 and its fluorinated analogues gave similar, positive results for Scott's (cobalt (II) thiocyanate) test, normally used as a presumptive test for cocaine, to those previously reported for the structurally similar diphenidine and 2-, 3- and 4-methoxphenidine (MXP), most likely due to the presence of tertiary amines in all [31]. However, the MT-45s did not give a positive result in the modified Scott's test, which allows them to be differentiated from diphenidine and the MXPs [McKenzie et al., unpublished data]. The MT-45s all gave a yellow result in the Mecke's test as did diphenidine and 2-, 3- and 4-MXP [McKenzie et al., unpublished data]. Diphenidine and the MT-45s produced similar responses to the Marquis test (immediate yellow) but were differentiated from the MXPs which produce a transient pink or red/brown reaction [30].

\section{Identification of seized material}

The seized tablet was analysed by GC-MS, ATR-FTIR spectroscopy and NMR spectroscopy. Presumptive testing provided the same results for the seized tablet as observed for 
Table $1{ }^{13} \mathrm{C},{ }^{1} \mathrm{H}$ and ${ }^{19} \mathrm{~F}$ nuclear magnetic resonance data for the seized tablet and a $2 \mathrm{~F}-\mathrm{MT}-45$ reference standard (ref. std.), with a structural numbering system as used by [16] and as shown in Fig. 1a

\begin{tabular}{|c|c|c|c|c|c|c|}
\hline \multirow[t]{2}{*}{ No. } & \multicolumn{3}{|l|}{$\begin{array}{l}\text { Seized sample in } \mathrm{CDCl}_{3} \\
\text { Chemical shifts, } \delta \text { in ppm }\end{array}$} & \multicolumn{3}{|l|}{$\begin{array}{l}\text { 2F-MT-45 ref. std. in } \mathrm{CDCl}_{3} \\
\text { Chemical shifts, } \delta \text { in ppm }\end{array}$} \\
\hline & ${ }^{1} \mathrm{H}$ & ${ }^{13} \mathrm{C}$ & ${ }^{19} \mathrm{~F}$ & ${ }^{1} \mathrm{H}$ & ${ }^{13} \mathrm{C}$ & ${ }^{19} \mathrm{~F}$ \\
\hline $2 / 6$ & $\begin{array}{l}2.58,2 / 6 \text { overlaps with } 3 / 5 \\
\text { total integral } 8 \mathrm{H}, \mathrm{br}\end{array}$ & 49.37, $\mathrm{CH}_{2}$ & & $\begin{array}{l}2.58,2 / 6 \text { overlaps with } 3 / 5, \\
\text { total integral } 8 \mathrm{H}, \text { br }\end{array}$ & $49.43, \mathrm{CH}_{2}$ & \\
\hline $3 / 5$ & $2.54, \mathrm{br}$ & $50.34, \mathrm{br}, \mathrm{CH}_{2}$ & & $2.55, \mathrm{br}$ & $50.42, \mathrm{br}, \mathrm{CH}_{2}$ & \\
\hline $1^{\prime}$ & $4.12,1 \mathrm{H}, \mathrm{dd}, J=9.6,5.6 \mathrm{~Hz}$ & $63.59 / 63.56^{*}, \mathrm{CH}$ & & $4.12,1 \mathrm{H}, \mathrm{dd}, J=9.7,5.6 \mathrm{~Hz}$ & $63.59 / 63.54^{*}, \mathrm{CH}$ & \\
\hline $2^{\prime}$ & $\begin{array}{l}3.32,1 \mathrm{H}, \mathrm{dd}, J=13.5 \\
5.6 \mathrm{~Hz} \\
3.04,1 \mathrm{H}, \mathrm{dd}, J=13.5 \\
9.6 \mathrm{~Hz}\end{array}$ & $38.43, \mathrm{CH}_{2}, \mathrm{~d}, J=1.2 \mathrm{~Hz}$ & & $\begin{array}{l}3.31,1 \mathrm{H}, \mathrm{dd}, J=13.5 \\
5.6 \mathrm{~Hz} \\
3.04,1 \mathrm{H}, \mathrm{dd}, J=13.5 \\
9.7 \mathrm{~Hz}\end{array}$ & $38.44, \mathrm{CH}_{2}, \mathrm{~d}, J=1.2 \mathrm{~Hz}$ & \\
\hline $1^{\prime}-1$ & - & $125.68, \mathrm{C}, \mathrm{d}, J=14.5 \mathrm{~Hz}$ & & - & $125.67, \mathrm{C}, \mathrm{d}, J=14.7 \mathrm{~Hz}$ & \\
\hline $1^{\prime}-2$ & - & $161.52, \mathrm{C}, \mathrm{d}, J=244.8 \mathrm{~Hz}$ & -119.6 & - & $161.53, \mathrm{C}, \mathrm{d}, J=244.8 \mathrm{~Hz}$ & -119.6 \\
\hline $1^{\prime}-3$ & $\begin{array}{l}6.88,1 \mathrm{H}, \mathrm{ddd}, J=10.2,8.2 \\
1.2 \mathrm{~Hz}\end{array}$ & $115.42, \mathrm{CH}, \mathrm{d}, J=23.8 \mathrm{~Hz}$ & & $\begin{array}{l}6.88,1 \mathrm{H}, \mathrm{ddd}, J=10.2,8.2 \\
1.2 \mathrm{~Hz}\end{array}$ & $115.43, \mathrm{CH}, \mathrm{d}, J=23.8 \mathrm{~Hz}$ & \\
\hline $1^{\prime}-4$ & $7.13,1 \mathrm{H}$, overlapping & $128.59, \mathrm{CH}, \mathrm{d}, J=8.5 \mathrm{~Hz}$ & & $7.13,1 \mathrm{H}$, overlapping & $128.56, \mathrm{CH}, \mathrm{d}, J=8.5 \mathrm{~Hz}$ & \\
\hline $1^{\prime}-5$ & $7.05,1 \mathrm{H}$, overlapping & $123.62, \mathrm{CH}, \mathrm{d}, J=3.4 \mathrm{~Hz}$ & & $7.05,1 \mathrm{H}$, overlapping & $123.61, \mathrm{CH}, \mathrm{d}, J=3.3 \mathrm{~Hz}$ & \\
\hline $1^{\prime}-6$ & $7.29,1 \mathrm{H}, \mathrm{td}, J=7.3,1.7 \mathrm{~Hz}$ & $130.05, \mathrm{CH}, \mathrm{d}, J=4.9 \mathrm{~Hz}$ & & $7.29,1 \mathrm{H}, \mathrm{td}, J=7.4,1.8 \mathrm{~Hz}$ & $130.06, \mathrm{CH}, \mathrm{d}, J=4.9 \mathrm{~Hz}$ & \\
\hline $2^{\prime}-1$ & - & $139.30, \mathrm{C}$ & & - & $139.35, \mathrm{C}$ & \\
\hline $2^{\prime}-2 / 2^{\prime}-6$ & $7.04,2 \mathrm{H}$, overlapping & $129.37, \mathrm{CH}$ & & $7.04,2 \mathrm{H}$, overlapping & $129.38, \mathrm{CH}$ & \\
\hline $2^{\prime}-3 / 2^{\prime}-5$ & $7.14,2 \mathrm{H}$, overlapping & $128.09, \mathrm{CH}$ & & $7.14,2 \mathrm{H}$, overlapping & $128.09, \mathrm{CH}$ & \\
\hline $2^{\prime}-4$ & $7.08,1 \mathrm{H}$ & $126.00, \mathrm{CH}$ & & $7.09,1 \mathrm{H}$ & $126.00, \mathrm{CH}$ & \\
\hline $1^{\prime \prime}$ & $\begin{array}{l}2.17,1 \mathrm{H}, \mathrm{tt}, J=10.9, \\
3.3 \mathrm{~Hz}\end{array}$ & $63.59 / 63.56^{*}, \mathrm{CH}$ & & $\begin{array}{l}2.17,1 \mathrm{H}, \mathrm{tt}, J=10.9, \\
3.3 \mathrm{~Hz}\end{array}$ & $63.54 / 63.59 *, \mathrm{CH}$ & \\
\hline $2 " / 6 "$ & $\begin{array}{l}1.86,2 \mathrm{H}, \mathrm{brd}, J=12.1 \mathrm{~Hz} \\
1.15,2 \mathrm{H}, \mathrm{m}\end{array}$ & $29.14,29.12, \mathrm{CH}_{2}$ & & $\begin{array}{l}1.86,2 \mathrm{H}, \mathrm{brd}, J=12.1 \mathrm{~Hz} \\
1.15,2 \mathrm{H}, \mathrm{m}\end{array}$ & $29.20,29.17, \mathrm{CH}_{2}$ & \\
\hline $3 " / 5 "$ & $\begin{array}{l}1.76,2 \mathrm{H}, \mathrm{brd}, J=13.0 \mathrm{~Hz} \\
1.19,2 \mathrm{H}, \mathrm{m}\end{array}$ & $26.02, \mathrm{CH}_{2}$ & & $\begin{array}{l}1.77,2 \mathrm{H}, \text { brd, } J=12.8 \mathrm{~Hz} \\
1.21,2 \mathrm{H}, \mathrm{m}\end{array}$ & $26.03, \mathrm{CH}_{2}$ & \\
\hline $4^{\prime \prime}$ & $\begin{array}{l}1.60,1 \mathrm{H}, \mathrm{m} \\
1.07,1 \mathrm{H}, \mathrm{qt}, J=12.4, \\
3.3 \mathrm{~Hz}\end{array}$ & $26.43, \mathrm{CH}_{2}$ & & $\begin{array}{l}1.60,1 \mathrm{H}, \mathrm{m} \\
1.07,1 \mathrm{H}, \mathrm{qt}, J=12.4 \\
3.5 \mathrm{~Hz}\end{array}$ & $26.46, \mathrm{CH}_{2}$ & \\
\hline
\end{tabular}

MT-45 and its fluorinated analogue reference standards. Preliminary GC-MS analysis indicated that it contained a previously unreported fluorinated MT-45 derivative rather than 2FPPP. The mass spectrum of the seized sample revealed a molecular ion at $m / z, 366$, and a comparison to the mass spectra of the MT-45 and 2F-MT-45 reference standards is provided in the supplementary material. MT- 45 could be chromatographically separated from the fluorinated MT$45 \mathrm{~s}$; however, the regioisomers could not be separated by retention time or mass using GC-MS. Comparison of the seized tablet with the synthesised reference standards using ATR-FTIR spectroscopy indicated that 2F-MT-45 was present with two discriminatory areas in the fingerprint region of the spectra, 800-650 nm and 1550-1400 nm (see supplementary material).

NMR spectroscopy data for the seized sample unequivocally confirmed the presence of 2F-MT-45 in the seized tablet along with unidentified excipients (Table 1). The data indicated the presence of a mono-fluorinated diphenylethyl group, a piperazine group (broadened by exchange processes) and a cyclohexane group. The connections between these groups and the position of the fluorine were determined using HMBC and NOESY/HOESY data (see supplementary material). The HMBC/NOESY/HOESY correlations to/from the 1 ' proton confirmed that the molecule was fluorinated at the 1'-2 position. This was further confirmed when the ${ }^{1} \mathrm{H}$ NMR and ${ }^{19} \mathrm{~F}$ NMR data from the F-MT-45 reference standards were compared with the seized sample (Figs. 3 and 4). The position of the fluorine singlet in the decoupled spectra showed the identical signals for the 2F-MT-45 and the seized sample (both $\delta:-119.6 \mathrm{ppm}$ ), and the proton-coupled data provides greater localised structural information and further evidence that the seized sample contains 2F-MT-45. To the author's knowledge, this is the first identification of a fluorinated MT-45 analogue in a seized sample. 


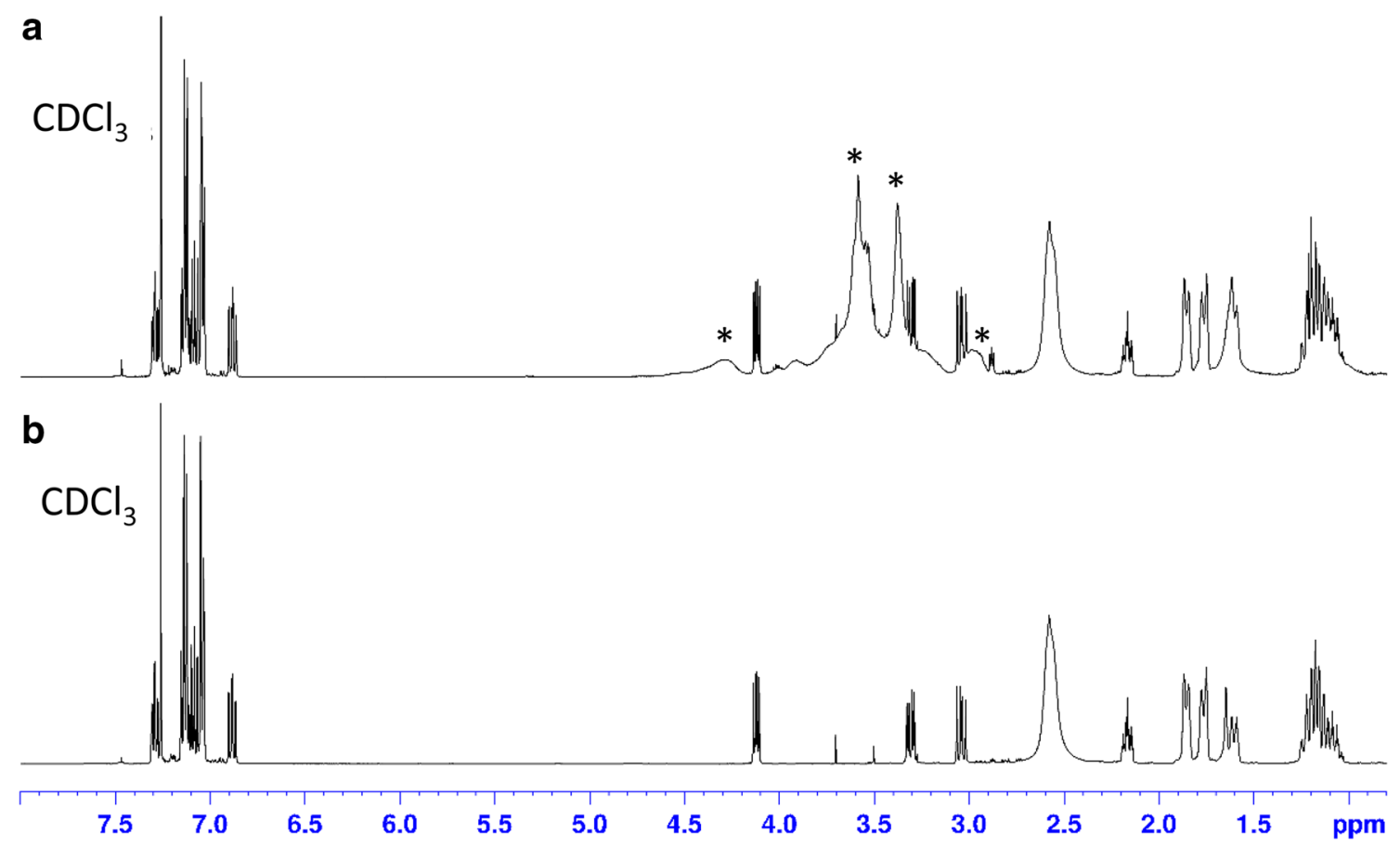

Fig. 3 a ${ }^{1} \mathrm{H}$ NMR data for the seized sample, and $\mathbf{b}{ }^{1} \mathrm{H}$ NMR data for the $2 \mathrm{~F}-\mathrm{MT}-45$ reference standard. *Signals presumed to be originating from unknown excipient(s) present in the seized sample

Fig. 4 Comparison of a proton decoupled and $\mathbf{b}$ proton-coupled ${ }^{19} \mathrm{~F}$ NMR spectra for the seized tablet from bag labelled " 2 FPPP" and the synthesised fluorinated MT45 reference standards $\mathbf{a}$

Seized sample

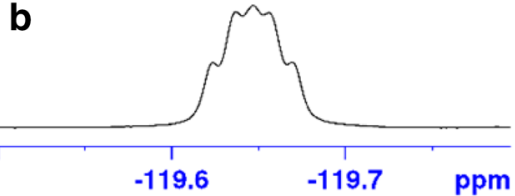

2F-MT45

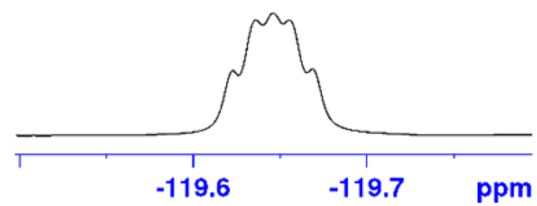

3F-MT45

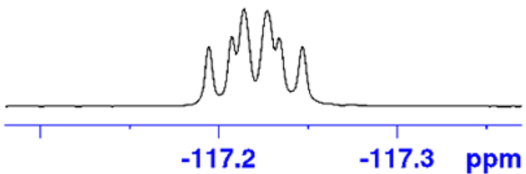

4F-MT45
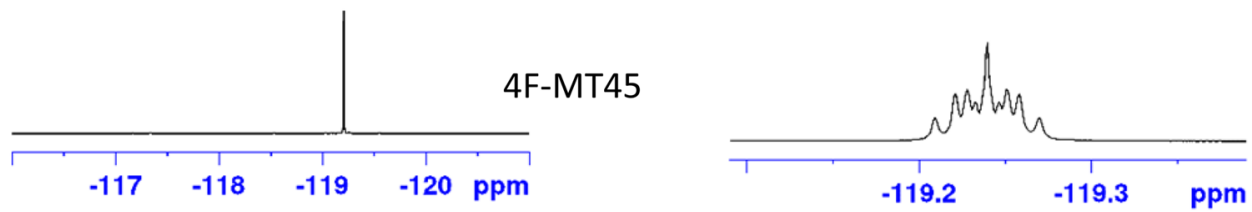

\section{Metabolite identification studies}

Metabolite identification studies were carried out using the synthesised MT-45 and 2F-MT-45 reference standards. No previous metabolite identification studies have been carried out on MT-45 using human liver microsomes or hepatocytes, although metabolites have previously been identified using rat hepatocytes and detected in mouse urine [12]. MT-45 has been reported in biological samples from fatal and nonfatal intoxications of drug users; however, no metabolites have been identified in human samples. 2F-MT-45 has not previously been reported in any intoxication cases and thus this work gives information on urinary metabolites should such a case arise in the future or to provide metabolite data to be 




Fig. 5 Overview of the metabolic profiling of MT-45 using human liver microsomes (HM), human hepatocytes (HH), mouse hepatocytes $(\mathrm{MH})$, mouse urine (MU) from in vivo testing and authenticated human urine (HU) samples. Product ion spectra and structural elucidation data are provided in the supplementary material, section $\mathrm{F}$

following 2F-MT-45 incubation with human liver microsomes, human hepatocytes, mouse hepatocytes and in vivo mouse studies, and these are summarised in Fig. 7 and Table 3 (2F-M1-2F-M12).

\section{Human in vitro studies}

Five phase I MT-45 metabolites were detected following human in vitro studies (Fig. 6b). No phase II metabolites were detected in the human in vitro studies, suggesting that hepatic phase II metabolism was limited by the incubation conditions employed in this study. Three metabolites were identified following incubation of MT-45 with human hepatocytes: M1, formed as a result of $\mathrm{N}$-dealkylation and M2 and M3, two mono-hydroxylated metabolites, (Figs. 5, 6a). Interestingly M1 (1,2-diphenylethylpiperazine) was not identified by Montesano et al. [12] in rat hepatocyte and mouse in vivo studies, who instead identified another $N$-dealkylated metabolite, 1-cyclohexyl-piperazine (labelled as M9 in that study, and M17 detected in human urine in this study).

M1 (1,2-diphenylethylpiperazine) was identified as one of three major metabolites, along with M2 and M3, using in vitro testing using human hepatocytes and human liver microsomes in this study and was also identified in verified 


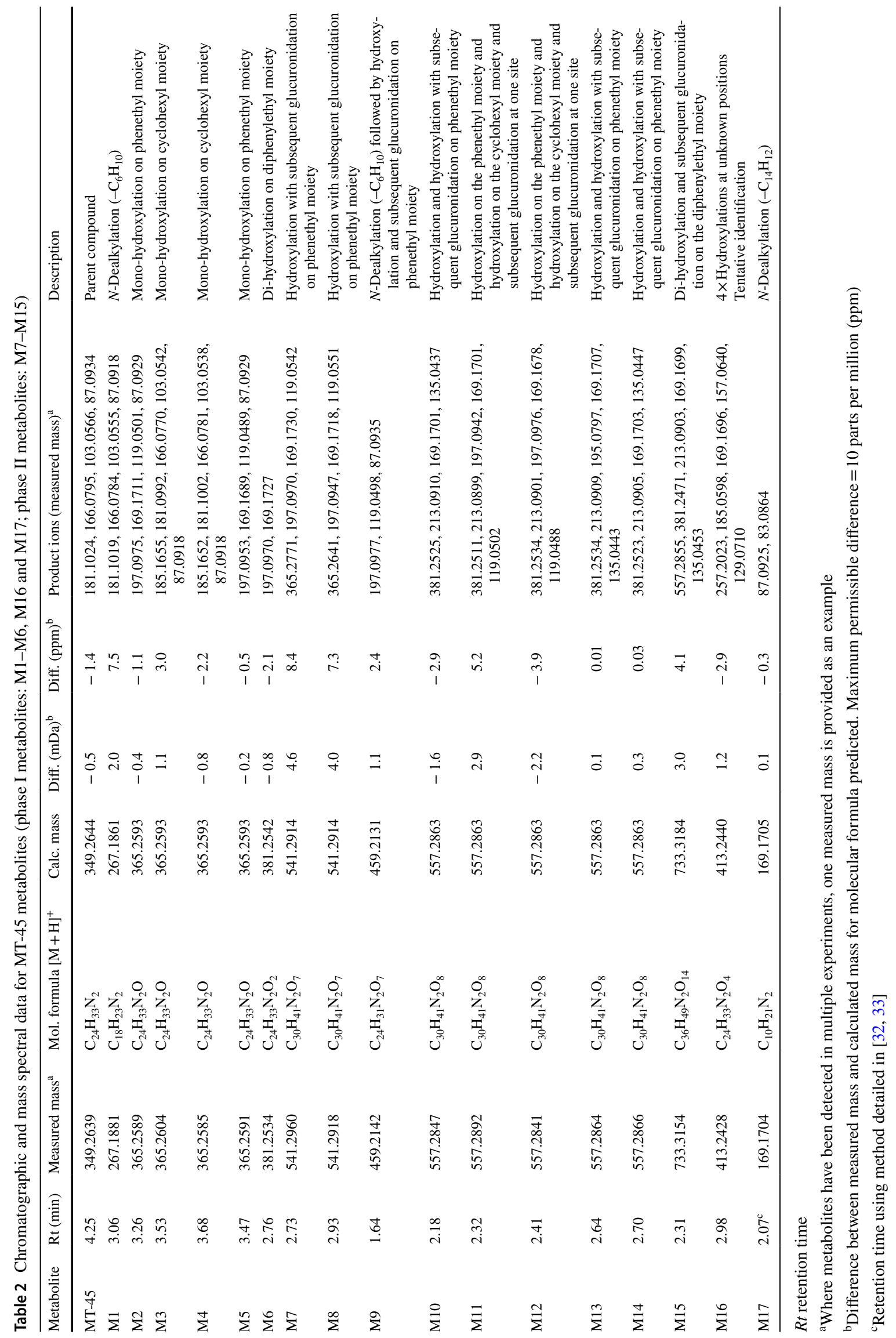




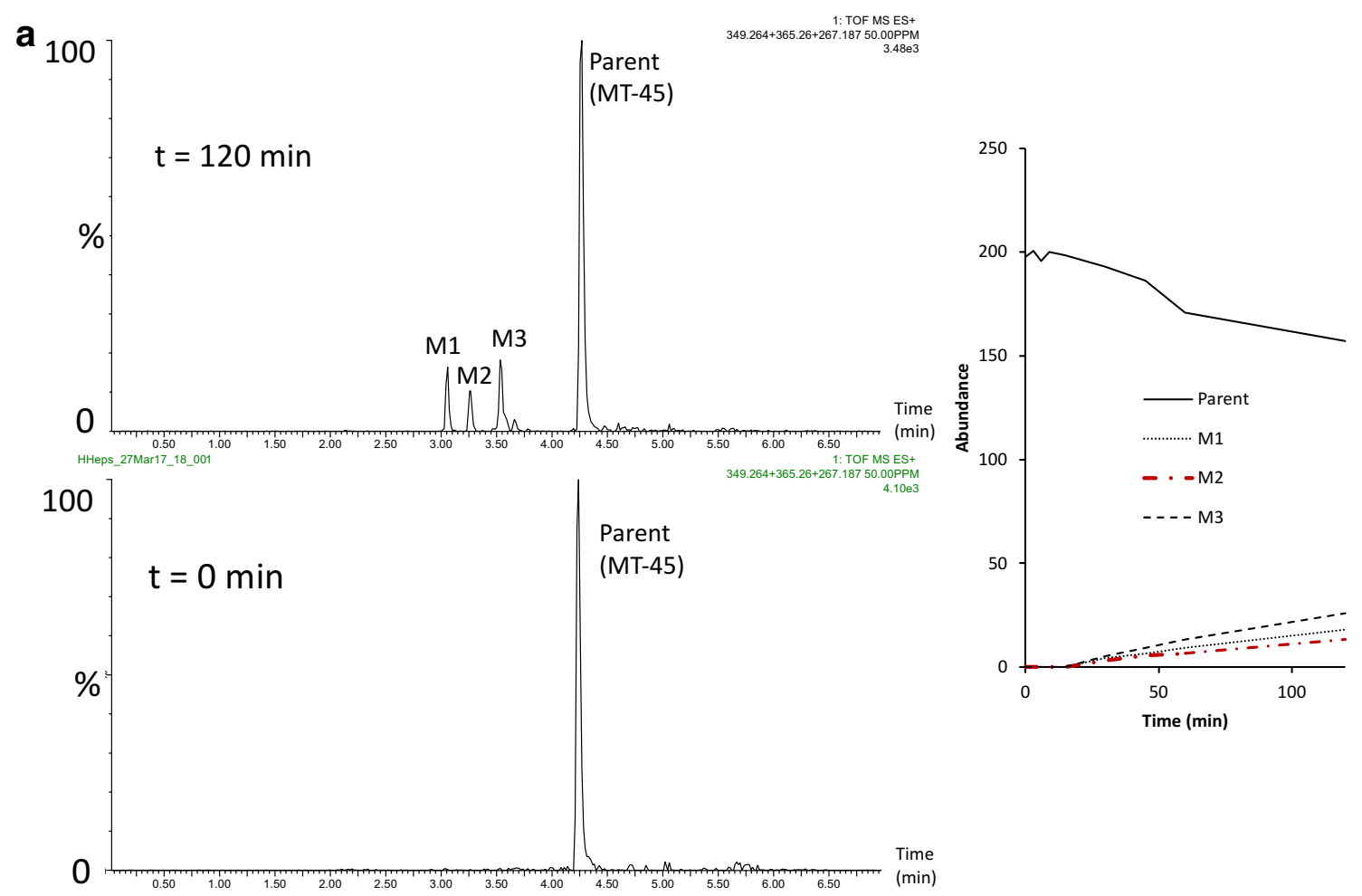

b

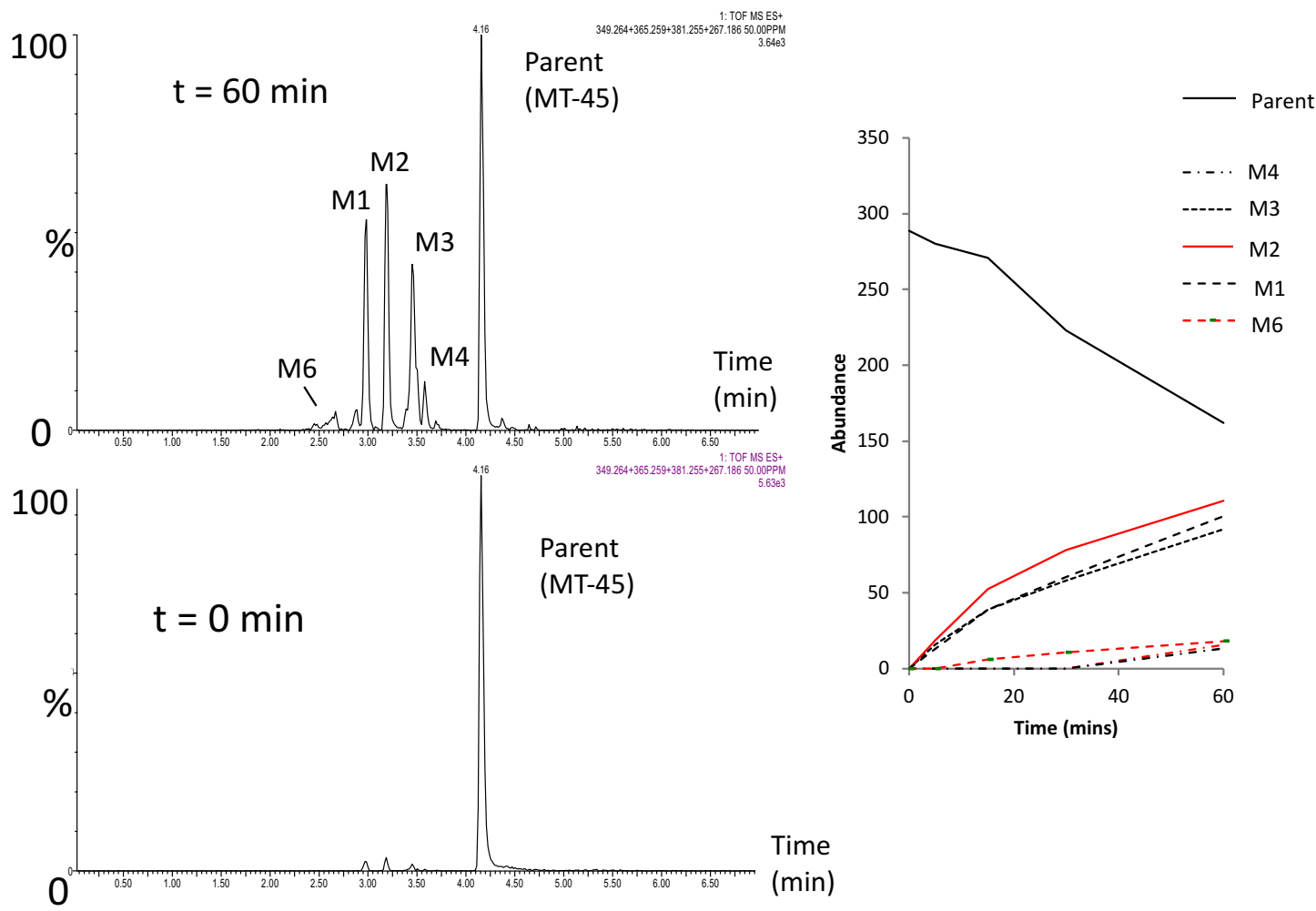

Fig. 6 Chromatographic profiles and time-course data following incubation of MT-45 with a human hepatocytes after $120 \mathrm{~min}$, and b human microsomes after $60 \mathrm{~min}$ obtained by ultra-performance liq- uid chromatography-quadrupole time-of-flight mass spectrometry. Metabolite labelling information can be found in Fig. 5 and Table 2 


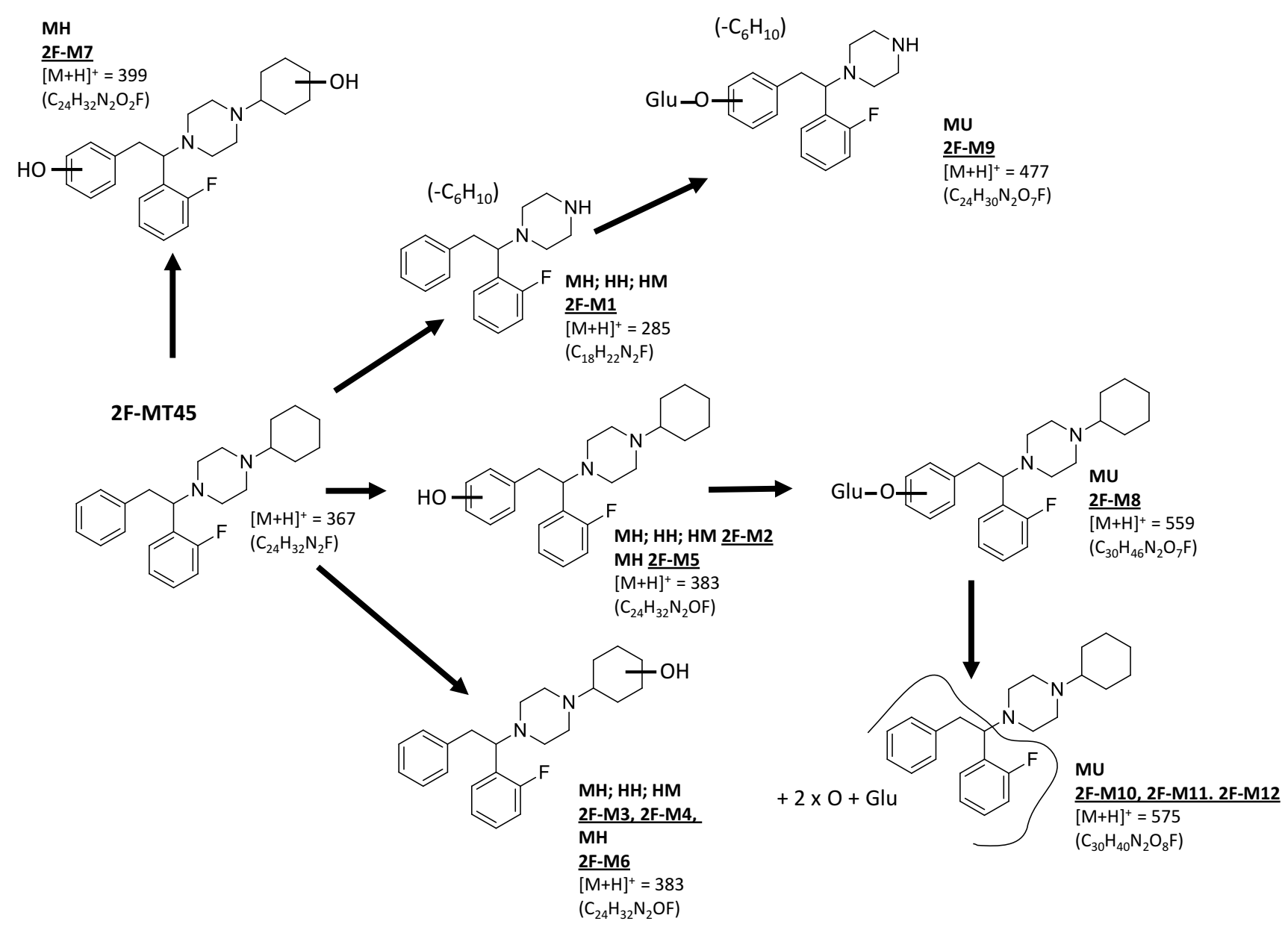

Fig. 7 Overview of the metabolic profiling of 2F-MT-45 using human liver microsomes (HM), human hepatocytes (HH), mouse hepatocytes $(\mathrm{MH})$ and mouse urine (MU) from in vivo testing. Prod- uct ion data and structural elucidation data are provided in supplementary material, section $\mathrm{G}$

mono-hydroxylated metabolites, 2F-M2, 2F-M3 and 2F-M4, were detected.

\section{Mouse in vitro studies}

Seven MT-45 metabolites were detected following incubation of MT-45 with mouse hepatocytes for $2 \mathrm{~h}$ (Fig. 5, Table 2; see supplementary material for chromatograms), three of which had not been observed previously in the human in vitro studies. M5 is hydroxylated on the phenethyl moiety similar to M2 detected in the human in vitro studies; M7 and M8 are phase II metabolites with glucuronidation occurring on the phenethyl moiety.

Seven 2F-MT-45 metabolites were detected following incubation of 2F-MT-45 with mouse hepatocytes (Fig. 7, Table 3), three of which (2F-M5, 2F-M6 and 
Table 3 Chromatographic and mass spectral data for 2F-MT-45 metabolites (phase I metabolites: 2F-M1-2F-M7; phase II metabolites: 2F-M8-2F-M12)

\begin{tabular}{|c|c|c|c|c|c|c|c|c|}
\hline Metabolite & $\mathrm{Rt}$ (min) & Measured mass ${ }^{\mathrm{a}}$ & $\begin{array}{l}\text { Mol. formula } \\
{[\mathrm{M}+\mathrm{H}]^{+}}\end{array}$ & Calc. mass & Diff. $(\mathrm{mDa})^{\mathrm{b}}$ & Diff. $(\mathrm{ppm})^{\mathrm{b}}$ & $\begin{array}{l}\text { Product ions (meas- } \\
\text { ured mass) }\end{array}$ & Description \\
\hline 2F-MT-45 & 4.54 & 367.2542 & $\mathrm{C}_{24} \mathrm{H}_{32} \mathrm{~N}_{2} \mathrm{~F}$ & 367.2550 & -0.8 & -2.2 & $\begin{array}{r}181.1024,166.0795 \\
103.0566,87.0934\end{array}$ & Parent compound \\
\hline 2F-M1 & 3.56 & 285.1782 & $\mathrm{C}_{18} \mathrm{H}_{22} \mathrm{~N}_{2} \mathrm{~F}$ & 285.1853 & 1.5 & 5.3 & $\begin{array}{l}199.0935,179.0660 \\
121.0463, \\
103.0548,87.0928\end{array}$ & $\begin{array}{l}N \text {-Dealkylation (- } \\
\left.\mathrm{C}_{6} \mathrm{H}_{10}\right)\end{array}$ \\
\hline 2F-M2 & 3.61 & 383.2505 & $\mathrm{C}_{24} \mathrm{H}_{32} \mathrm{~N}_{2} \mathrm{OF}$ & 383.2499 & 0.6 & & $\begin{array}{r}215.0671,169.1721, \\
119.0499,87.0938\end{array}$ & $\begin{array}{l}\text { Mono-hydroxylation } \\
\text { on the phenethyl } \\
\text { moiety }\end{array}$ \\
\hline 2F-M3 & 3.88 & 383.2500 & $\mathrm{C}_{24} \mathrm{H}_{32} \mathrm{~N}_{2} \mathrm{OF}$ & 383.2499 & 0.2 & 0.4 & $\begin{array}{l}199.0925,179.0862 \\
121.0455\end{array}$ & $\begin{array}{l}\text { Mono-hydroxylation } \\
\text { on the cyclohexyl } \\
\text { moiety }\end{array}$ \\
\hline 2F-M4 & 4.01 & 383.2517 & $\mathrm{C}_{24} \mathrm{H}_{32} \mathrm{~N}_{2} \mathrm{OF}$ & 383.2499 & 1.9 & 4.9 & $\begin{array}{l}199.0925,179.0862 \\
121.0455\end{array}$ & $\begin{array}{l}\text { Mono-hydroxylation } \\
\text { on the cyclohexyl } \\
\text { moiety }\end{array}$ \\
\hline 2F-M5 & 3.78 & 383.2501 & $\mathrm{C}_{24} \mathrm{H}_{32} \mathrm{~N}_{2} \mathrm{OF}$ & 383.2499 & 0.3 & 0.7 & $\begin{array}{r}215.0907,169.1737 \\
119.0499,87.0938\end{array}$ & $\begin{array}{l}\text { Mono-hydroxylation } \\
\text { on the phenethyl } \\
\text { moiety }\end{array}$ \\
\hline 2F-M6 & 4.13 & 383.2495 & $\mathrm{C}_{24} \mathrm{H}_{32} \mathrm{~N}_{2} \mathrm{OF}$ & 383.2499 & -0.3 & -0.7 & $\begin{array}{l}199.0919,185.1661 \\
121.0455\end{array}$ & $\begin{array}{l}\text { Mono-hydroxylation } \\
\text { on the cyclohexyl } \\
\text { moiety }\end{array}$ \\
\hline 2F-M7 & 2.90 & 399.2441 & $\mathrm{C}_{24} \mathrm{H}_{32} \mathrm{~N}_{2} \mathrm{O}_{2} \mathrm{~F}$ & 399.2488 & -0.7 & -1.8 & $\begin{array}{l}215.0913,185.1647 \\
119.0524\end{array}$ & $\begin{array}{l}\text { Di-hydroxylation on } \\
\text { the cyclohexyl and } \\
\text { phenethyl moieties }\end{array}$ \\
\hline 2F-M8 & 3.16 & 559.2765 & $\mathrm{C}_{30} \mathrm{H}_{46} \mathrm{~N}_{2} \mathrm{O}_{7} \mathrm{~F}$ & 559.2820 & -5.5 & -9.8 & $\begin{array}{l}215.0852,119.0488 \\
87.0926\end{array}$ & $\begin{array}{l}\text { Hydroxylation with } \\
\text { subsequent glucu- } \\
\text { ronidation on the } \\
\text { phenethyl moiety }\end{array}$ \\
\hline 2F-M9 & 1.95 & 477.2039 & $\mathrm{C}_{24} \mathrm{H}_{30} \mathrm{~N}_{2} \mathrm{O}_{7} \mathrm{~F}$ & 477.2037 & 0.2 & 0.4 & $\begin{array}{l}215.0854,119.0488 \\
87.0926\end{array}$ & $\begin{array}{l}N \text {-Dealkylation (- } \\
\mathrm{C}_{6} \mathrm{H}_{10} \text { ) followed by } \\
\text { hydroxylation with } \\
\text { subsequent glucu- } \\
\text { ronidation on the } \\
\text { phenethyl moiety }\end{array}$ \\
\hline 2F-M10 & 2.43 & 575.2762 & $\mathrm{C}_{30} \mathrm{H}_{40} \mathrm{~N}_{2} \mathrm{O}_{8} \mathrm{~F}$ & 575.2769 & -0.7 & -1.2 & $\begin{array}{l}399.2435,231.0826 \\
169.1708 \\
135.0448\end{array}$ & $\begin{array}{l}\text { Hydroxylation and } \\
\text { hydroxylation } \\
\text { with subsequent } \\
\text { glucuronidation on } \\
\text { the 2-fluorophenyl } \\
\text { phenethyl moiety }\end{array}$ \\
\hline 2F-M11 & 2.87 & 575.2729 & $\mathrm{C}_{30} \mathrm{H}_{40} \mathrm{~N}_{2} \mathrm{O}_{8} \mathrm{~F}$ & 575.2769 & -4.0 & -7.0 & $\begin{array}{l}399.2461,231.0807 \\
169.1704\end{array}$ & $\begin{array}{l}\text { Hydroxylation and } \\
\text { hydroxylation } \\
\text { with subsequent } \\
\text { glucuronidation on } \\
\text { the 2-fluorophenyl } \\
\text { phenethyl moiety }\end{array}$ \\
\hline 2F-M12 & 2.97 & 575.2726 & $\mathrm{C}_{30} \mathrm{H}_{40} \mathrm{~N}_{2} \mathrm{O}_{8} \mathrm{~F}$ & 575.2769 & -4.3 & -7.5 & $\begin{array}{l}399.2433,231.0811 \\
169.1712\end{array}$ & $\begin{array}{l}\text { Hydroxylation and } \\
\text { hydroxylation } \\
\text { with subsequent } \\
\text { glucuronidation on } \\
\text { the 2-fluorophenyl } \\
\text { phenethyl moiety }\end{array}$ \\
\hline
\end{tabular}

\section{$R t$ retention time}

${ }^{a}$ Where metabolites have been detected in multiple experiments, one measured mass is provided as an example

${ }^{\mathrm{b}}$ Difference between measured mass and calculated mass for molecular formula predicted. Maximum permissible difference $=10$ parts per million (ppm)

2F-M7) had not been detected in the human in vitro studies. Metabolite 2F-M5, like 2F-M2, was hydroxylated on the phenethyl moiety; 2F-M6 is a minor metabolite which, like 2F-M3 and 2F-M4, was hydroxylated on the cyclohexyl moiety; 2F-M7 was dihydroxylated, with one hydroxylation on the phenethyl moiety and the other on 
the cyclohexyl moiety. The most prominent metabolites were the mono-hydroxylated 2F-M3 and 2F-M4 ( $/ 2 / z, 383)$ metabolites.

\section{Mouse in vivo studies}

No MT-45 was detected in mouse urine collected after $24 \mathrm{~h}$ [see supplementary material, section E(ii)] and 10 metabolites were detected. Phase II (glucuronidated) metabolites were the most abundant as estimated by peak area, in agreement with previous findings in mouse urine [12]. Metabolite M9 was the glucuronidated form of the $N$-dealkylated metabolite M1. Metabolites M10-M14 contained one hydroxyl group and one hydroxyl group with subsequent glucuronidation. M11 and M12 were hydroxylated on both the cyclohexyl moiety and phenethyl moiety with one hydroxyl group being subsequently glucuronidated. M10, M13 and M14 were di-hydroxylated on the phenethyl moiety, as indicated by the product ion at $m / z 135$ with one hydroxyl group being subsequently glucuronidated. Metabolite M15 was di-hydroxylated and subsequently glucuronidated on the diphenylethyl moiety.

No 2F-MT-45 was detected in mouse urine collected after $24 \mathrm{~h}$. Five glucuronidated metabolites were identified (Fig. 7, Table 3). Metabolite 2F-M8 was hydroxylated and subsequently glucuronidated on the phenethyl moiety. Metabolite 2F-M9 was the glucuronidated form of 2F-M1. Three other metabolites containing one hydroxyl group and one hydroxyl group with subsequent glucuronidation on the 2-fluorophenyl phenethyl moiety were detected: 2F-M10, 2F-M11 and 2F-M12.

\section{Confirmatory identification of MT-45 metabolites in human urine}

All MT-45 metabolites identified in the human and mouse in vitro and mouse in vivo studies (M1-M16) were detected in the human urine samples obtained from two analytically confirmed cases of MT-45 intoxication (Fig. 5), confirming the applicability of the methodology to case samples. The relative concentrations of metabolites were similar in both cases with M1 and M3 being the major metabolites, followed by M2 and M4 (each about 50\% response in UPLC-QToFMS as compared with M1 and M3), M5 and M6 (about 25\%), M7-M9, M12 and M17 ( 5-10\%), and finally M10, M11, M13, M15 and M16 ( 1\% or less). An additional metabolite, M17, was detected in the human urine samples with similar peak areas to M5 and M6 (25-30\% of M1 and M3). This $N$-dealkylated metabolite had not been identified in the human in vitro, the mouse in vitro and mouse in vivo studies using female C57 mice in this work, but had been previously identified as a significant metabolite in a study using rat hepatocytes and male ICR $\left(\mathrm{CD}-1^{\circledR}\right)$ mice [12].

\section{Discussion}

2F-MT-45 was detected in a single seized tablet and its identity confirmed by comparison with in-house synthesised reference standards. It is noteworthy that there was some discrimination of the regioisomers using ATR-FTIR spectroscopy and Raman spectroscopy; however, they were most clearly distinguished using NMR spectroscopy, without the need to compare the resulting data with reference standards for structural elucidation. The sample was supplied in packaging labelled 2FPPP, indicating the presence of a dissociative drug with some structural similarities to $2 \mathrm{~F}-\mathrm{MT}$ 45. As far as the authors are aware, 2F-MT-45 has not been previously detected and the reasoning behind its synthesis in this case (deliberate or accidental) is unknown. This tablet was received for testing prior to the ban on production and export of MT-45 in China in July 2017 [29] and so it is possible that such compounds may enter the illicit drugs market in the future; however, MT-45 itself was relatively unpopular with users and a range of serious and unusual side effects have been linked with the drug $[17,20]$.

Both human hepatocyte and human liver microsomal incubations produced major $N$-dealkylated metabolites of MT-45 (M1) and 2F-MT-45 (2F-M1) which have structural similarities to dissociative drugs such as diphenidine and 2-FPPP. Although the same metabolites (M1 and 2F-M1) were observed after incubation with mouse hepatocytes, they were less prominent, suggesting that $N$-dealkylation is more efficiently expressed in the human in vitro systems. It is postulated that these metabolites, structurally related to diphenidine, will not be excreted directly via the kidney into urine but will instead be recirculated in plasma, and they are more likely to have a larger distribution volume in the body. It is hypothesised that these metabolites are pharmacologically active and will interact with NMDA receptors once recirculated, and that they may be responsible, at least in part, for the dissociative effects of MT- 45 reported by some users. Further studies of the pharmacological activity of M1 (and 2F-M1) against opioid and NMDA receptors are required to test this hypothesis.

Cryopreserved primary human hepatocytes such as those used in this study provide a model in vitro metabolite identification solution. They incorporate natural hepatic metabolic enzyme systems, co-substrates for phase I and II metabolism at physiological levels, and intact drug transporter systems. They are theoretically most likely to provide an authentic range of human metabolites in metabolite identification studies [34, 35]. They are, however, expensive relative to other in vitro systems and are relatively more complex to use than microsomes, require incubation under carbogen and have lower intracellular glutathione (GSH) and glutathione$S$-transferase (GST) activities than fresh hepatocytes. This 
means that, if occurring in vivo, GSH conjugation of MT-45 and 2F-MT45 may have been missed in vitro, although no evidence for GSH or GST conjugation was observed in the mouse in vivo study. In addition, human hepatocytes have a finite lifetime in suspension cultures (up to $5 \mathrm{~h}$, although their activity is likely to decrease significantly after $2-3 \mathrm{~h}$ ) and thus alternative in vitro systems are often used instead. Human liver microsomes represent a relevant system (and a more cost-effective approach) if the metabolism of the chemicals in question is known to be due to microsomal enzymes. In this study, the metabolites identified using human hepatocytes and human microsomes were very similar and three of the major MT-45 metabolites detected in human urine were also the major metabolites detected in the human in vitro methods. The use of pooled human S9 fraction or human liver microsomes combined with human cytosol has also been proposed as an alternative for NPS metabolomics studies focussed on identifying urinary target metabolites for toxicological screening purposes $[36,37]$.

The present study utilised a wide range of methodologies. MT-45 and 2F-MT-45 incubation with human hepatocytes produced relatively lower amounts of metabolites (and less metabolites) as compared to incubations with human liver microsomes (see Fig. 6 for MT-45 data). In both the human hepatocyte and human liver microsome experiments, only phase I metabolites were identified, suggesting that phase II metabolism of MT-45 and 2F-MT-45 is either very slow, or is extrahepatic, and these metabolites were not identified in the in vitro models used. Some minor phase II metabolism was observed in the mouse hepatocytes and these were also reported after MT-45 incubation with rat hepatocytes [12].

\section{Conclusions}

A new fluorinated analogue of MT-45, 2F-MT-45, has been unequivocally identified in an illicitly produced tablet for the first time. The substance was identified using presumptive testing, GC-MS, UPLC-QToF-MS, ATR-FTIR spectroscopy, Raman spectroscopy and NMR spectroscopy in comparison to fully characterised in-house synthesised reference standards for MT-45 and 2F-, 3F- and 4F-MT-45. Metabolic profiling has been carried out for MT-45 and 2F-MT-45, and HRMS data for the identified metabolites has been reported in human in vitro testing for the first time. The presence of the identified MT-45 metabolites has been also confirmed in authenticated human urine samples. It is recommended that the protonated molecular ions of the parent and major metabolites (M1-M4 and 2F-M1-2F-M4) are added to toxicological screening methods, and that, where possible, HRMS data from previous analyses are re-examined using data-mining techniques to increase the toxicovigilance information available on the prevalence and use of such compounds in different jurisdictions.

Acknowledgements S. A. Smith is funded by the Engineering and Physical Sciences Research Council (EPSRC) Doctoral Training Programme. The authors acknowledge the work of L. Ellis of the Drug Discovery Unit, University of Dundee for Physico-Chemical Analysis and Y. Shishikura, F. Simeons, L. Ferguson, E. Pinto and L. Stojanovski also of the Drug Discovery Unit, University of Dundee; and S. Ward for presumptive testing. S. Ward was funded by a Royal Society of Chemistry Analytical Chemistry Trust Fund internship grant.

\section{Compliance with ethical standards}

Conflict of interest There are no financial or other relations that could lead to a conflict of interest.

Ethical approval All procedures performed in this study involving human participants were in accordance with the ethical standards of the international and/or national committee and with the 1964 Declaration of Helsinki and its later amendments or comparable ethical standards. The two authentic human urine samples were collected as part of the STRIDA project which is conducted in accordance with the Helsinki Declaration and was approved by the regional ethical review board (Nr. 2013/116-31/2). All regulated procedures on living animals at the University of Dundee were carried out under the authority of a project licence issued by the Home Office under the Animals (Scientific Procedures) Act 1986, as amended in 2012 (and in compliance with EU Directive EU/2010/63). Licence applications were approved by the University's Ethical Review Committee (ERC) before submission to the Home Office. The ERC has a general remit to develop and oversee policy on all aspects of the use of animals on University premises and is a subcommittee of the University Court, its highest governing body.

Open Access This article is distributed under the terms of the Creative Commons Attribution 4.0 International License (http://creativeco mmons.org/licenses/by/4.0/), which permits unrestricted use, distribution, and reproduction in any medium, provided you give appropriate credit to the original author(s) and the source, provide a link to the Creative Commons license, and indicate if changes were made.

\section{References}

1. Baumann MH, Majumdar S, Le Rouzic V, Hunkele A, Uprety R, Huang XP, Xu J, Roth BL, Pan Y-X, Pasternak GW (2017) Pharmacological characterization of novel synthetic opioids (NSO) found in the recreational drug marketplace. Neuropharmacology. https://doi.org/10.1016/j.neuropharm.2017.08.016

2. EMCDDA (2014) EMCDDA-Europol Joint Report on a new psychoactive substance: 1-cyclohexyl-4-(1,2-diphenylethyl)piperazine ('MT-45'). http://www.emcdda.europa.eu/system/files/publicatio ns/810/TDAS14007ENN_477731.pdf_en. Accessed 25 Aug 2017

3. European Patent Office (1976) 1-Substituted-4-(1,2-diphenylethyl) piperazine derivatives and their salts and the preparation thereof. US Patent 3,957,788. Issued 18th May 1976. https://worldwide. espacenet.com/publicationDetails/biblio?CC $=\mathrm{US} \& \mathrm{NR}=39577$ $88 \& \mathrm{KC}=\& \mathrm{FT}=\mathrm{E} \&$ locale $=$ en_EP. Accessed 21 Aug 2017

4. Nakamura H, Shimizu M (1976) Comparative study of 1-(cyclohexyl-4-(1,2-diphenylethyl)- piperazine (MT-45) and its 
enantiomorphs on analgesic and other pharmacological activities in experimental animals. Arch Int Pharmacodyn Ther 221:105-121

5. Prekupec M, Mansky P, Baumann M (2017) Misuse of novel synthetic opioids: a deadly new trend. J Addict Med 11:256-265

6. Zawilska JB (2017) An expanding world of novel psychoactive substances: opioids. Front Psychiatry 8:110. https://doi. org/10.3389/fpsyt.2017.00110

7. Matsuno K, Senda T, Kobayashi T, Murai M, Mita S (1998) Reduction of 4-cyclohexyl-1- [(1R)-1,2-diphenylethyl]-piperazine-induced memory impairment of passive avoidance performance by sigma1 receptor agonists in mice. Methods Find Exp Clin Pharmacol 20:575-580

8. Fujimura H, Tsurumi K, Nozaki M, Hori M, Imai E (1978) Analgesic activity and opiate receptor binding of 1-cyclohexyl-4-(1,2diphenylethyl)piperazine. Jpn J Pharmacol 28:505-506

9. Nozaki M, Niwa M, Imai E, Hori M, Fujimura H (1983) (1,2-Diphenylethyl)piperazines as potent opiate-like analgesics: the unusual relationships between stereoselectivity and affinity to opioid receptor. Life Sci 33(Suppl 1):431-434

10. Natsuka K, Nakamura H, Uno H, Umemoto S (1975) Studies on 1-substituted 4-(1,2-diphenylethyl)piperazine derivatives and their analgesic activities. J Med Chem 18:1240-1244

11. Natsuka K, Nakamura $H$, Nishikawa $Y$, Negoro $T$, Uno $H$, Nishimura H (1987) Synthesis and structure-activity relationships of 1-substituted 4-(1,2-diphenylethyl) piperazine derivatives having narcotic agonist and antagonist activity. J Med Chem 30:1779-1787

12. Montesano C, Vannutelli G, Fanti F, Vincenti F, Gregori A, Togna AR, Canazza I, Marti M, Sergi M (2017) Identification of MT-45 metabolites: in silico prediction, in vitro incubation with rat hepatocytes and in vivo confirmation. J Anal Toxicol 41:688-697

13. Erowid (2014) A few trials: an experience with MT-45 (exp103454). https://erowid.org/experiences/exp.php?ID=10345 4. Accessed 20 Sep 2017

14. Erowid (2015) Mild but fun: an experience with MT-45 (exp105759). https://erowid.org/experiences/subs/exp. php?ID=105759. Accessed 20 Sep 2017

15. BlueLight (2017) (RC's) MT-45 (1-cyclohexyl-4-(1,2-diphenylethyl)piperazine). http://www.bluelight.org/vb/threads/64056 4-MT-45-(1-cyclohexyl-4-(1-2-diphenylethyl)piperazine). Accessed 20 Oct 2017

16. Uchiyama N, Matsuda S, Kawamura M, Kikura-Hanajiri R, Goda Y (2014) Identification of two new-type designer drugs, piperazine derivative MT-45 (I-C6) and synthetic peptide Noopept (GVS-111), with synthetic cannabinoid A-834735, cathinone derivative 4-methoxy- $\alpha$-PVP, and phenethylamine derivative 4-methylbuphedrine from illegal products. Forensic Toxicol 32:9-18

17. Helander A, Backberg M, Beck O (2014) MT-45, a new psychoactive substance associated with hearing loss and unconsciousness. Clin Toxicol 52:901-904

18. EMCDDA (2015) Report on the risk assessment of MT-45 in the framework of the Council Decision on new psychoactive substances. http://www.emcdda.europa.eu/system/files/publicatio ns/1865/TDAK14006ENN.pdf_en. Accessed 25 Aug 2017

19. Helander A, Beck O, Hägerkvist R, Hultén P (2013) Identification of novel psychoactive drug use in Sweden based on laboratory analysis-initial experiences from the STRIDA project. Scand J Clin Lab Invest 73:400-406

20. Helander A, Bradley M, Hasselblad A, Norlén L, Vassilaki I, Bäckberg M, Lapins J (2017) Acute skin and hair symptoms followed by severe, delayed eye complications in subjects using the synthetic opioid MT-45. Br J Dermatol 176:1021-1027

21. Papsun D, Krywanczyk A, Vose JC, Bundock EA, Logan BK (2016) Analysis of MT-45, a novel synthetic opioid, in human whole blood by LC-MS-MS and its identification in a drugrelated death. J Anal Toxicol 40:313-317

22. US Immigration and Custom Enforcement (2014) HSI seizes websites selling potentially deadly illegal narcotics. https://www.ice. gov/news/releases/hsi-seizes-websites-selling-potentially-deadl y-illegal-narcotics. Accessed 1 Aug 2017

23. Fels H, Krueger J, Sachs H, Musshoff F, Graw M, Roider G, Stoever A (2017) Two fatalities associated with synthetic opioids: AH-7921 and MT-45. Forensic Sci Int 277:e30-e35

24. UK Government (2015) Circular 003/2015: a change to the Misuse of Drugs Act 1971: control of MT-45 and 4,4'-DMAR. https:// www.gov.uk/government/publications/circular-0032015-a-chang e-to-the-misuse-of-drugs-act-1971-control-of-mt-45-and-44dmar. Accessed 25 Jul 2017

25. UNODC (2016) Decision 59/2. Inclusion of MT-45 in Schedule I of the Single Convention on Narcotic Drugs of 1961 as amended by the 1972 Protocol. https://www.unodc.org/documents/commi ssions/CND/CND_Sessions/CND_59/Decision_59_2.pdf. Accessed 25 Aug 2017

26. WHO (2015) MT-45 critical review report-Expert Committee on Drug Dependence, thirty seventh meeting Geneva. http://www. who.int/medicines/access/controlled-substances/5.1_MT-45_ CRev.pdf. Accessed 25 Aug 2017

27. Siddiqi S, Verney C, Dargan P, Wood D (2015) Understanding the availability, prevalence of use, desired effects, acute toxicity and dependence potential of the novel opioid MT-45. Clin Toxicol 53:54-59

28. Kjellgren A, Jacobsson K, Soussan C (2016) The quest for wellbeing and pleasure: experiences of the novel synthetic opioids AH-7921 and MT-45, as reported by anonymous users online. J Addict Res Ther 7:287. https://doi.org/10.4172/2155-6105.10002 87

29. Associated Press (2017) China bans more synthetic opioids blamed for US drug deaths 2017. https://www.statnews. com/2017/06/19/synthetic-opioids-fentanyl-china/. Accessed 25 Aug 2017

30. Geyer PM, Hulme MC, Irving JPB, Thompson PD, Ashton RN, Lee RJ, Johnson L, Marron J, Banks CE, Sutcliffe OB (2016) Guilty by dissociation-development of gas chromatography mass spectrometry (GC-MS) and other rapid screening methods for the analysis of 13 diphenidine-derived new psychoactive substances (NPSs). Anal Bioanal Chem 408:8467-8481

31. UNODC (1995) Rapid testing methods of drugs of abuse. https ://www.unodc.org/documents/scientific/Rapid_Testing_Metho ds_of_Drugs_of_Abuse_E.pdf. Accessed 29 Jun 2016

32. Petterson Bergstrand M, Meyer MR, Beck O, Helander A (2017) Human urinary metabolic patterns of the designer benzodiazepines flubromazolam and pyrazolam studied by liquid chromatography-high resolution mass spectrometry. Drug Test Anal. https://doi.org/10.1002/dta.2243

33. Stephanson NN, Signell P, Helander A, Beck O (2017) Use of LC-HRMS in full scan-XIC mode for multi-analyte urine drug testing-a step towards a "black-box" solution? J Mass Spectrom 52:497-506

34. Li AP (2007) Human hepatocytes: isolation, cryopreservation and applications in drug development. Chem Biol Interact 168:16-29

35. Wohlfarth A, Vikingsson S, Roman M, Andersson M, Kugelberg FC, Green H, Kronstrand R (2017) Looking at flubromazolam metabolism from four diferent angles: metabolite profiling in human liver microsomes, human hepatocytes, mice and authentic human urine samples with liquid chromatography high-resolution mass spectrometry. Forensic Sci Int 274:55-63

36. Richter LHJ, Flockerzi V, Maurer HH, Meyer MR (2017) Pooled human liver preparations, HepaRG, or HepG2 cell lines for metabolism studies of new psychoactive substances? A study using 
MDMA, MDBD, butylone, MDPPP, MDPV, MDPB, 5-MAPB, and 5-API as examples. J Pharm Biomed Anal 143:32-42

37. Richter LHJ, Maurer HH, Meyer MR (2017) New psychoactive substances: studies on the metabolism of XLR-11, AB-PINACA,
FUB-PB-22, 4-methoxy- $\alpha$-PVP, 25-I-NBOMe, and meclonazepam using human liver preparations in comparison to primary human hepatocytes, and human urine. Toxicol Lett 280:142-150 